\title{
Irrigation improves plant vitality in specific stages of mango tree development according to photosynthetic efficiency
}

\author{
L. FARIA-SILVA*, C. Z. GALLON*, P. R. FILGUEIRAS ${ }^{* *}$, and D. M. SILVA*,+ \\ Photosynthesis Research Center, Federal University of Espirito Santo, 514 Fernando Ferrari Avenue, $29075-910$ \\ Vitoria, ES, Brazil ${ }^{*}$ \\ Chemistry Graduate Program, Federal University of Espirito Santo, 514 Fernando Ferrari Avenue, 29075-910 \\ Vitoria, ES, Brazil ${ }^{* *}$
}

\begin{abstract}
The plant fruiting process requires more energy and availability of soil water. Consequently, identifying the appropriate time for additional water supplying for cultivation of mango is an important part of successful crop handling for production of fruit with high quality. Therefore, we studied effects of additional water supplied by irrigation on chlorophyll fluorescence parameters in a field experiment during phenological stages of Mangifera indica L. cv. Ubá. Our results showed that the irrigation at specific periods of plant development improved fluorescence parameters (resulting in high values of the performance index), preventing damage of the photosynthetic apparatus, which positively influenced the supply of photoassimilates to fruit load. Furthermore, the results suggest that the additional water supply by irrigation in rainfed mango trees is recommended for maintaining high photosynthetic performance just during fruit development and fruit maturation.
\end{abstract}

Additional key words: drought stress; JIP test; postharvest; ripening; water management.

\section{Introduction}

Brazil is one of the largest fruit producers in the world, and the production of 'Ubá' mango for processing is promising, due to the current demand of the world market for mango pulp and fruit juice (Oliveira et al. 2016). However, the water deficit is known to change a variety of biochemical and physiological processes, ranging from photosynthesis to protein synthesis and solute accumulation, which limits plant productivity (Wang et al. 2003).

Irrigation management in Palmer and Tommy Atkins mango orchards is well described in the literature (Lucena et al. 2007); however, no details are known about the effects of water supply on photosynthetic efficiency during different phenological stages. Water deficit prevents vegetative shoots from flushing in mango trees. It is assumed that water stress is necessary for a possible floral stimulus to accumulate (Carr 2014). For the next stages of development, it is important that the plants are wellwatered and under conditions of high temperatures ( $\mathrm{Lu}$ and Chacko 2000, Laxman et al. 2016). Therefore, the oscillations in the distribution of rainfall during the year may alter the cycle of mango trees managed under rainfed conditions. Consequently, changes in leaf physiological metabolism and fruit production may occur (Davenport 2007, Ripoll et al. 2014). Beside other metabolic processes occurring in plants, photosynthesis was shown to be a process sensitive to water availability (Kalaji et al. 2017, Stirbet et al. 2018).

It has been documented that the adequate production of photoassimilates depends on the proper functioning of the photosynthesis. The influence of the changes of environmental conditions on the physiology of photosynthetic apparatus of plants has been often studied using the fluorescence of chlorophyll (Chl) a (Strasser et al. 2004, Jedmowski et al. 2013, Einali and Shariati 2015). This technique allows to obtain qualitative and quantitative information on the physiological conditions of the photosynthetic apparatus, and can eventually be correlated with the productivity of the plants (Stirbet et al. 2014, Van Wittenberghe et al. 2015). The fruiting process in the plant requires more energy and availability of soil water (Laxman et al. 2016). Moreover, under water stress and prolonged high temperatures, there is a higher respiratory

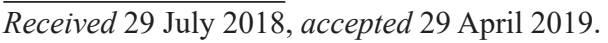

${ }^{+}$Corresponding author; phone +55 27 4009.7609, +55 27 99941.9445, e-mail: diolina.silva@ufes.br

Abbreviations: Car - carotenoids; Chl - chlorophyll; $\mathrm{DF}_{\mathrm{ABS}}$ - driving force on absorption basis; $\mathrm{DI}_{0} / \mathrm{RC}^{-}$flux of energy dissipated in processes other than trapping per active PSII; $\mathrm{ET}_{0} / \mathrm{RC}$ - flux of electrons transferred from $\mathrm{Q}_{\mathrm{A}}^{-}$to plastoquinone per active PSII; $\mathrm{PI}_{\mathrm{ABS}}$ - performance index on absorption basis; $\mathrm{PI}_{\mathrm{TOTAL}}$ - total performance index on absorption basis; $\mathrm{Q}_{\mathrm{A}}^{-}$- reduced plastoquinone electron acceptor of PSII; $\mathrm{RE}_{0} / \mathrm{RC}$ - flux of electrons transferred from $\mathrm{Q}_{\mathrm{A}}^{-}$to final PSI acceptors per active PSII; TA - total titratable acidity; TSS - total soluble solids.

Acknowledgements: The authors thank the Brazilian Federal Agency for Support and Evaluation of Graduate Education (CAPES, Finance Code 001), and the National Counsel of Technological and Scientific Development (CNPq). The authors also thank the farmers Eduardo Gabler and José Gon who made available the orchards and the fruits.
} 
demand and a loss of photoassimilates (Pongsomboon et al. 1997, González et al. 2004). Therefore, in times of drought, the supply of water during specific stages of plant development is expected to maintain photoassimilate production.

In view of the above mentioned, the effects of drought on the photochemical performance of mango trees is of paramount importance for fruit quality. Due to environmental changes, prolonged drought season has become frequent in areas that were usually well-watered by rain. In these conditions, the photosynthetic performance of 'Ubá' mango tree has changed the production of photoassimilates, which may reflect on the quality of the fruits. Thus, the objective of this work was to evaluate the photosynthetic efficiency of mango trees during reproductive cycle, and to determine the adequate stage of plant development during which irrigation can improve the vitality of the plants.

\section{Materials and methods}

Plant material and growth conditions: Eight-year-old 'Ubá' mango (Mangifera indica L.) trees were acquired from a commercial orchard of 'Mango Pole' located in Colatina, Espirito Santo, Brazil (19³2'32.71"S, 4045'49.73"W, alt. $209 \mathrm{~m}$ ). The trees were planted with $9.0 \times 9.0 \mathrm{~m}$ spacing under rainfed and irrigation conditions. The study was conducted with 20 plants for each water regime: irrigated and nonirrigated conditions. The irrigation was interrupted during the flowering stage for both water regimes; at this stage, both irrigated and nonirrigated plants received only rain water. The irrigation frequency was estimated in the orchard according to the daily evapotranspiration registered by an irrigameter (Irrigâmetro ${ }^{\circledR}$, Federal University of Viçosa, Brazil) installed at the orchard, and calculations were based on Oliveira et al. (2008).

The total annual precipitation was $476 \mathrm{~mm}$. The recorded rainfall distribution for each phenological stage was obtained from the meteorological station of the National Institute of Meteorology (INMET) (Aimorés, MG/Brazil, $19^{\circ} 31^{\prime} 57.96^{\prime \prime S}, 41^{\circ} 05^{\prime} 26.88^{\prime \prime} \mathrm{W}$, alt. $288 \mathrm{~m}$ ) from January to December 2015 (Fig. 1).

The samples for chemical and physiological analysis were collected according to Hernández Delgado et al. (2011), starting with vegetative bud development to the end of fruit maturity. Leaves and fruits were analyzed during six phenological stages: stage I - before pruning, stage II after pruning, stage III - vegetative flush, stage IV flowering, stage V - fruit development, and stage VI - fruit maturity.

Chl $\boldsymbol{a}$ fluorescence measurements: The Chl $a$ fluorescence induction of 'Ubá' mango leaves was measured between 7:00-9:00 h with a plant efficiency analyzer (Handy PEA, Hansatech Instruments Ltd., King's Lynn, Norfolk, UK). All measurements were recorded in the morning because the radiation in the latter hours affects the OJIP-derived parameters (Kalaji et al. 2016). The measurements were done in triplicates, on fully expanded leaf after $40 \mathrm{~min}$ of adaptation to darkness. The kinetics of Chl $a$ fluorescence was measured using a saturating red-light pulse of about

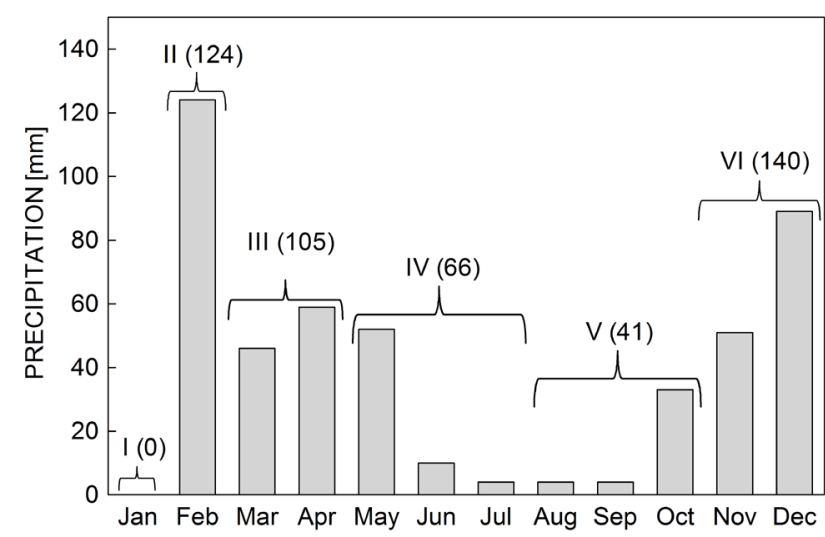

Fig. 1. Rainfall distribution for each phenological stage of mango plants obtained from the meteorological station of the National Institute of Meteorology (INMET) (Aimorés, MG/Brazil) $\left(19^{\circ} 31^{\prime} 57.96 " \mathrm{~S}, 41^{\circ} 05^{\prime} 26.88^{\prime \prime} \mathrm{W}\right.$, alt. $\left.288 \mathrm{~m}\right)$ from January to December. Stage I - before pruning; stage II - after pruning; stage III - vegetative flush; stage IV - flowering; stage V fruit development; stage VI - fruit maturity. The total annual precipitation was $476 \mathrm{~mm}$.

3,000 $\mu \mathrm{mol}$ (photon) $\mathrm{m}^{-2} \mathrm{~s}^{-1}$. Fluorescence intensities were recorded between $20 \mu \mathrm{s}$ and $1 \mathrm{~s}$; the fluorescence at $20 \mu \mathrm{s}$ was considered the initial fluorescence $\left(\mathrm{F}_{0}\right)$, and the maximum fluorescence $\left(\mathrm{F}_{\mathrm{M}}\right)$ was reached at $\sim 400$ $\mathrm{ms}$. Several fluorescence parameters, i.e., $\mathrm{F}_{0}, \mathrm{~F}_{\mathrm{M}}, \mathrm{F}_{\mathrm{V}} /$ $\mathrm{F}_{\mathrm{M}}, \mathrm{dV} / \mathrm{dt}_{0}, \mathrm{dVG} / \mathrm{dt}_{0}, \mathrm{ABS} / \mathrm{RC}, \mathrm{DI}_{0} / \mathrm{RC}, \mathrm{TR}_{0} / \mathrm{RC}, \mathrm{ET}_{0} /$ $\mathrm{RC}, \mathrm{RE}_{0} / \mathrm{RC}, \psi \mathrm{E}_{0}, \delta \mathrm{R}_{0}, \varphi \mathrm{P}_{0}, \varphi \mathrm{E}_{0}, \varphi \mathrm{R}_{0}, \mathrm{PI}_{\mathrm{ABS}}, \mathrm{DF}_{\mathrm{ABS}}$, $\mathrm{PI}_{\text {TOtAL }}, \mathrm{DF}_{\mathrm{TOTAL}}, \mathrm{RC} / \mathrm{ABS}, \mathrm{RC} / \mathrm{CS}_{0}$ were calculated according to the so-called JIP test (Appendix), which is often used for $\mathrm{Chl} a$ fluorescence induction analysis, and is based on the Biomembrane Energy Flow Theory (see Strasser and Strasser 1995, Strasser et al. 2004, 2010; Stirbet and Govindjee 2011).

Photosynthetic pigment measurements: Chl $a$ and $b$ contents and total carotenoids (Car) of the leaves used for fluorescence measurements were determined in triplicate according to Lichtenthaler and Buschmann (2001). Approximately $100 \mathrm{mg}$ of leaves, corresponding to eight discs of $0.5 \mathrm{~cm}^{2}$, were macerated with $7 \mathrm{~mL}$ of acetone $80 \%(\mathrm{v} / \mathrm{v})$. The macerate was filtered with filter paper to a volumetric flask and the volume was completed to $25 \mathrm{~mL}$. The filtrate was protected from light to avoid photodegradation. The optical absorption of the filtrate was determined with a spectrophotometer (Genesys $10 \mathrm{~S}$ UV-Vis, Thermo Scientific) at 470, 646.8, and $663.2 \mathrm{~nm}$.

Evaluation of fruit quality: Fruit sampling was done at unripe and ripe stages for each water regime. As shown in Yashoda et al. (2006), unripe fruits (from irrigated and nonirrigated plants) were harvested with greenish skin color, when shoulders were fully developed. The fruits were washed with a solution containing sodium hypochlorite solution and kept at $25^{\circ} \mathrm{C}$ for $7 \mathrm{~d}$ prior to daily analyses. Ten ripe fruits with yellowish skin, considered prior to consumption, were harvested totally ripe and analyzed one day after the harvest. 
The fruits were peeled and cut, and the pulp was ground in a Grindomix blender (Retsch, Haan, Germany). The resulted juice was used for the measurement of total soluble solids (TSS $\left[{ }^{\circ}\right.$ Brix]) content and total titratable acidity (TA [g(citric acid equivalent) $100 \mathrm{~g}^{-1}$ (pulp)]). Total soluble solids were determined using a refractometer (Atago ATC-1E, Tokyo, Japan). Total titratable acidity (up to $\mathrm{pH} 8.1$ ) was measured with a titrameter using a $0.1 \mathrm{~N}$ $\mathrm{NaOH}$ solution. The fresh mass was measured on in natura fruits using a semi-analytical balance with a precision of \pm $0.01 \mathrm{~g}$. The physiological mass loss (PWL) was calculated as: $\mathrm{PWL}_{n}[\%]=\left[\left(\mathrm{W}_{0}-\mathrm{W}_{\mathrm{n}}\right) / \mathrm{W}_{0}\right] \times 100$, where $\mathrm{PWL}_{\mathrm{n}}$ is the physiological mass loss in percent for each stage of maturation; $\mathrm{W}_{0}$ is the initial mass of the sample in $g$ at the first day of storage; and $\mathrm{W}_{\mathrm{n}}$ is the mass of the sample for each maturation stage. Respiration rates were measured using LCpro-SD (ADC BioScientific Ltd., UK) portable infrared gas analyzer (IRGA) calibrated with standard $\mathrm{CO}_{2}$ of $380 \mu \mathrm{mol} \mathrm{mol}{ }^{-1}$. A single mango fruit was placed in $1-\mathrm{L}$ airtight chamber covered with black cloth, and air was passed through the chamber(model LCI/LCpro SoilhoodV2, ADC BioScientific Ltd., UK). The flow rate of the air was adjusted to $200 \mu \mathrm{mol} \mathrm{s}{ }^{-1}$. Respiration was expressed in $\operatorname{mmol}\left(\mathrm{CO}_{2}\right) \mathrm{kg}^{-1}(\mathrm{FM}) \mathrm{h}^{-1}$.

Statistical analysis: Fisher's weights and PCA (principal component analysis) were used to analyze differences and similarities of the JIP test parameters calculated for both water regimes (Skrobot et al. 2007). The most significant parameters were determined using MATLAB software version 8.1 (MathWorks, Inc., USA). Analysis of variance (ANOVA) was performed to assess the effect of irrigation regime on the vegetative and reproductive characteristics of the tree. Multiples analysis was performed using the Tukey's test $(p \leq 0.05)$ to evaluate whether or not the means were significantly different. All statistical analyses were computed using Statistical Analysis Software (SAS, version 9.0).

\section{Results}

Water regime influence on $\mathrm{Chl}$ a fluorescence parameters: The fluorescence parameters which better identified the differences and similarities according to PCA analysis are presented in Fig. 2. This multivariate analysis of 21 different fluorescence parameters obtained by the JIP test indicated six more representative parameters of Chl $a$ fluorescence $\left(\mathrm{ET}_{0} / \mathrm{RC}, \mathrm{RE}_{0} / \mathrm{RC}, \mathrm{PI}_{\mathrm{ABS}}, \mathrm{DF}_{\mathrm{ABS}}, \mathrm{DI}_{0} / \mathrm{RC}\right.$, $\mathrm{PI}_{\text {TOTAL }}$ ) which differentiated two water regimes (irrigated and nonirrigated) in each one of six periods analyzed (I, II, III, IV, V, and VI).

Water availability positively influenced the photochemical phase of photosynthesis before pruning (stage I) of mango trees, and also during fruit development (stage $\mathrm{V}$ ) and maturity of the fruit (stage VI) (Fig. 3). In stage I, the irrigated plants had values of the initial electron transport flux at the PSII level $\left(\mathrm{ET}_{0} / \mathrm{RC}\right)$ and electron transfer flow to the final acceptors of the PSI $\left(\mathrm{RE}_{0} / \mathrm{RC}\right)$ that were 10 and $20 \%$ higher than that for the nonirrigated plants, respectively. Also, during fruit development (stage V), irrigated plants had higher performance index $\left(\mathrm{PI}_{\mathrm{ABS}}\right)$, higher driving force $\left(\mathrm{DF}_{\mathrm{ABS}}\right)$, and higher $\mathrm{ET}_{0} / \mathrm{RC}$ compared to nonirrigated plants. Furthermore, the plants irrigated during the fruit-maturity period (stage VI) showed a lower dissipated excitation energy at the PSII level $\left(\mathrm{DI}_{0} / \mathrm{RC}\right)$ and higher $\mathrm{RE}_{0} / \mathrm{RC}$, which led to an increase by $60 \%$ of the total performance index $\left(\mathrm{PI}_{\text {TOTAL }}\right)$ in well-watered plants. In contrast, the use of irrigation influenced negatively the photosynthetic electron transport in stages II and III (after pruning and during vegetative flush), due to high energy dissipation $\left(\mathrm{DI}_{0} / \mathrm{RC}\right)$, which was $40 \%$ higher in irrigated plants compared to nonirrigated plants in stage II, and

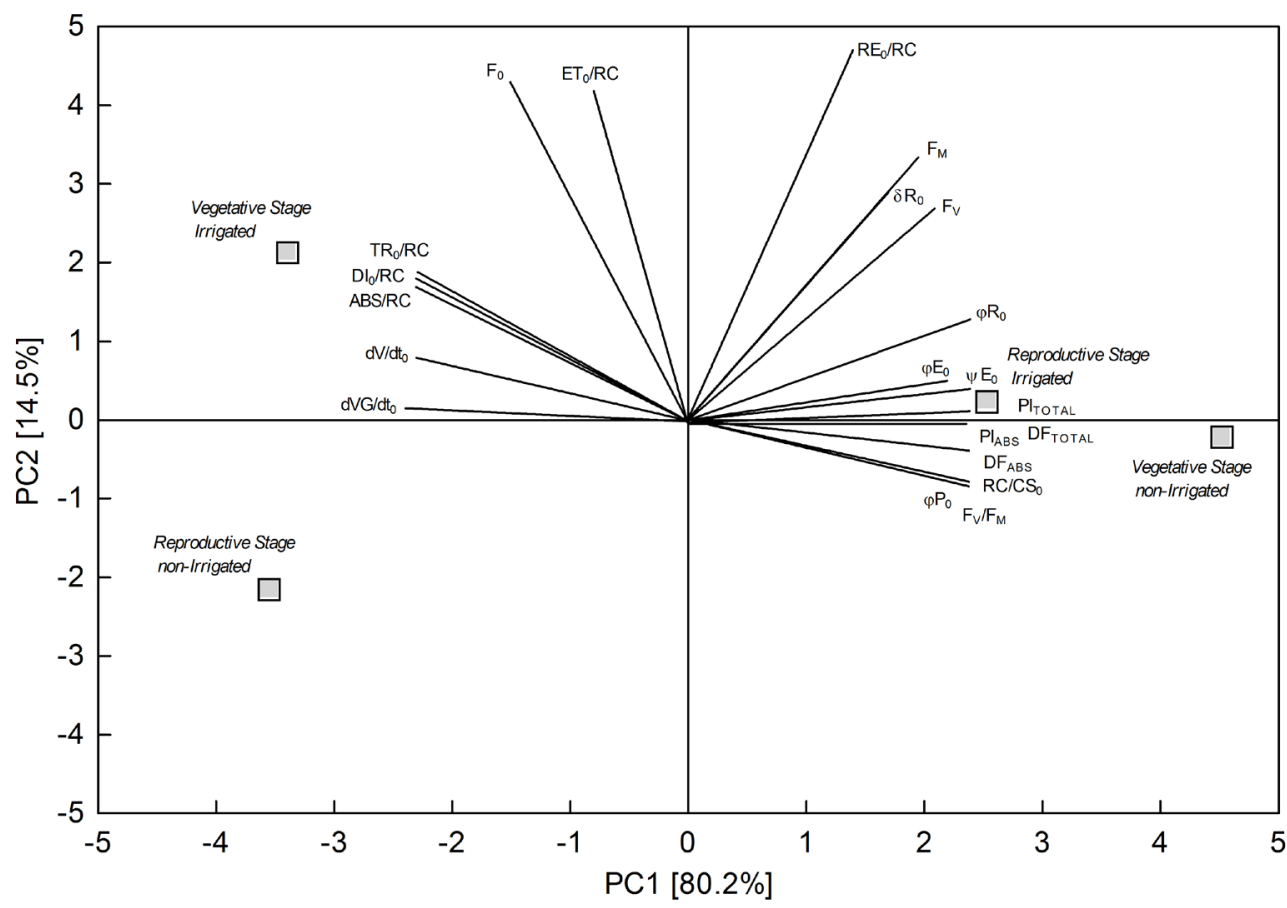

Fig. 2. Results of the principal components analysis (PCA) used to analyze differences and similarities of the JIP test parameters calculated for the both water regimes (irrigated and nonirrigated) at vegetative (stages I, II, III) and reproductive (stages IV, V, VI) stages of mango development. Of 21 different fluorescence parameters obtained by JIP test, this multivariate analysis indicated six more representative (in bold). 


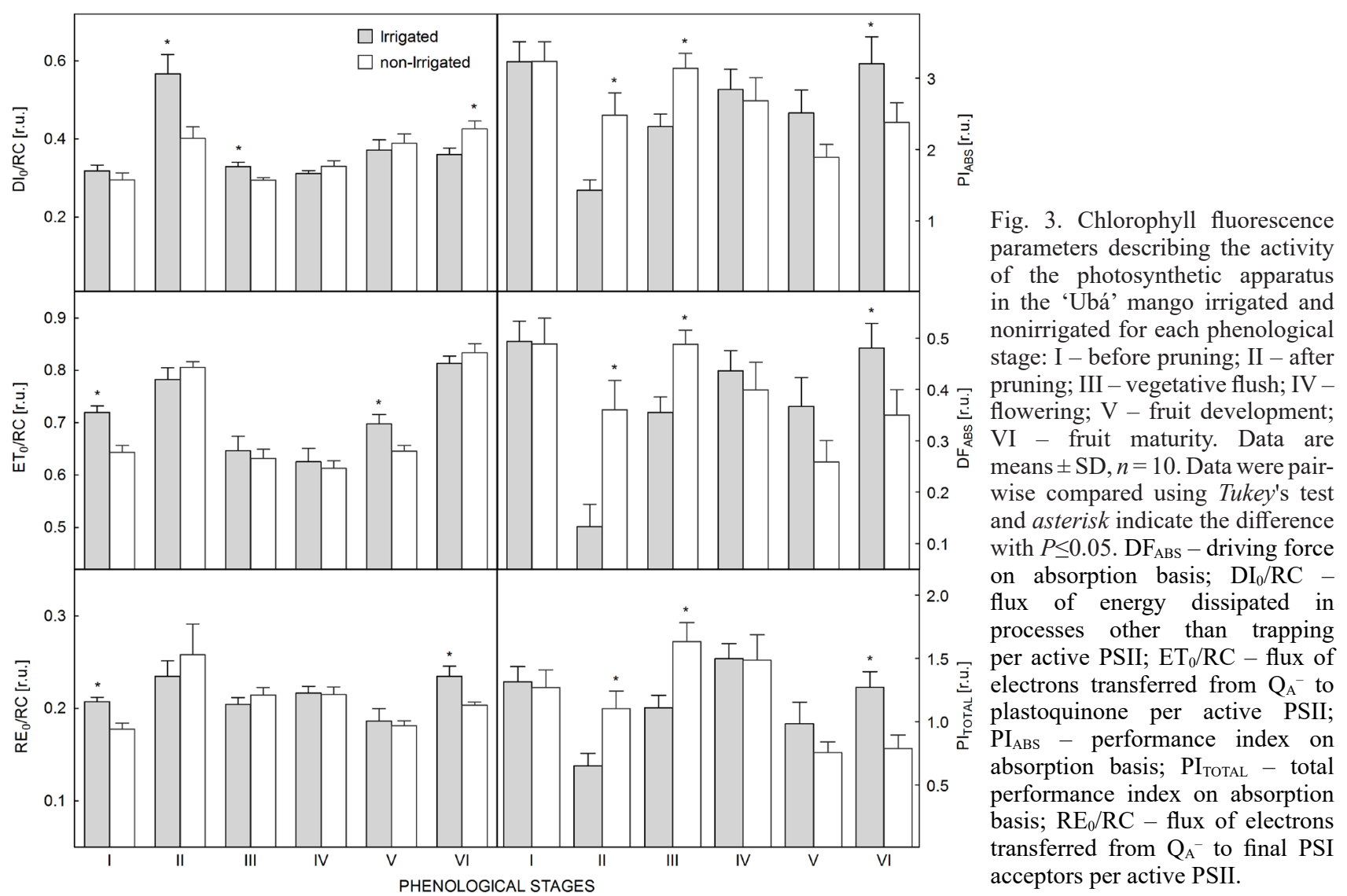

$10 \%$ in stage III. We also observed that additional water in stages II and III had a negative impact in irrigated plants, as indicated by the decrease in $\mathrm{PI}_{\mathrm{ABS}}$ and $\mathrm{DF}_{\mathrm{ABS}}$ by 40 and $60 \%$, respectively, compared to nonirrigated plants in the stage II (Fig. 3), whereas the parameters of photochemical performance $\left(\mathrm{PI}_{\mathrm{ABS}}\right), \mathrm{PI}_{\mathrm{TOTAL}}$, and $\mathrm{DF}_{\mathrm{ABS}}$ decreased by 25 , 30 , and $27 \%$, respectively, in the stage III. The flowering stage (IV) was the only phenological stage in which the water regime had no significant influence on any $\mathrm{Chl} a$ fluorescence parameter.

Photosynthetic pigments: Irrigation water supply positively influenced the synthesis of total Chl during the flowering stage (stage IV) (Table 1). Irrigated plants had $43 \mu \mathrm{g}$ (total $\mathrm{Chl}) \mathrm{cm}^{-2}$ and a $\mathrm{Chl} a / b$ ratio of 3.42 , while nonirrigated plants showed $33 \mu \mathrm{g}$ (total $\mathrm{Chl}) \mathrm{cm}^{-2}$, and the $\mathrm{Chl} a / b$ ratio of 2.91. During the stages I, II, V, and VI, the total Chl content of the irrigated plants $(21,45,17$, and $16 \mu \mathrm{g} \mathrm{cm}^{-2}$, respectively) were negatively affected, since in the nonirrigated plants, the Chl contents were higher (29, 47,36 , and $21 \mu \mathrm{g} \mathrm{cm}^{-2}$, respectively). Furthermore, the Chl $a / b$ ratio in stage I was 2.79 in irrigated plants, and 3.32 in nonirrigated plants. During fruit development (stage $\mathrm{V})$, the Chl $a / b$ ratio was 2.00 in well-watered plants, and 2.95 in the nonirrigated plants. After pruning (stage II) and during fruit development (stage V), no significant differences were observed between both water regimes. Likewise, no significant differences in total Chl were observed in irrigated and nonirrigated plants during the vegetative stage (stage III).
Table 1 also shows the total Car content for irrigated and nonirrigated plants during the six phenological stages. Irrigated plants at stage I, II, V, and VI $(2.37,4.70,2.52$, and $2.30 \mu \mathrm{g} \mathrm{cm}^{-2}$, respectively) showed a reduction in the Car content compared to nonirrigated plants $(2.86,5.25$, 3.86 , and $2.89 \mu \mathrm{g} \mathrm{cm}^{-2}$, respectively). During vegetative flush and flowering (stages III and IV), no differences were observed between the two water regimes.

Physical, chemical, and physiological analysis of the fruits: Differences in physicochemical parameters measured during the ripening process of mango fruits in two groups of trees are presented in Fig. 4. High TSS values of nonirrigated plants were observed from day 3 after harvest, while the TA values decreased over the ripening, reaching $\sim 0.4 \mathrm{~g}$ (citric acid) $100 \mathrm{~g}^{-1}$ (pulp) at the end of the ripening process. In general, we observed an increase in the content of TSS, a reduction in the titratable acidity, and consequently, an increase in the TSS/TA ratio, regardless of the water regime to which the trees were submitted. Punctually, from 5 to $7 \mathrm{~d}$ of storage at $25^{\circ} \mathrm{C}$, the fruits harvested as green, did not present an increase in the values of TSS, TA, and TSS/TA ratio, compared to the ripe fruits, independently of the water regime. An exception was observed for the fruit mass, as the fruits harvested ripe presented a higher fresh mass $(125 \mathrm{~g})$ than the fruit harvested at the physiological maturity (104 g). The respiratory activity in the fruits of irrigated plants was lower than that in fruits of nonirrigated plants; $2 \mathrm{~d}$ after harvest, the $\mathrm{CO}_{2}$ production was $0.37 \mathrm{mmol}\left(\mathrm{CO}_{2}\right) \mathrm{kg}^{-1}(\mathrm{FM}) \mathrm{h}^{-1}$ 
Table 1. Content of chloroplast pigments of the leaves from irrigated and nonirrigated Ubá mango trees during different phenological stages. Data are means $\pm \mathrm{SD}, n=6$. * indicates significant difference between irrigated and nonirrigated plants within each phenological stage ( $P \leq 0.05$, Tukey's test).

\begin{tabular}{llllll}
\hline Phenological stage & Water regime & Chl $(a+b)\left[\mu \mathrm{cm}^{-2}\right]$ & Car $\left[\mu \mathrm{g} \mathrm{cm}^{-2}\right]$ & Chl $a / b$ & Chl/Car \\
\hline Before pruning (stage I) & irrigated & $21.17 \pm 0.25$ & $147.44 \pm 4.24$ & $2.79 \pm 0.11$ & $0.14 \pm 0.00$ \\
& nonirrigated & $28.76 \pm 0.03^{*}$ & $177.85 \pm 0.51^{*}$ & $3.22 \pm 0.02^{*}$ & $0.16 \pm 0.00^{*}$ \\
After pruning (stage II) & irrigated & $44.98 \pm 0.43$ & $292.45 \pm 13.20$ & $3.06 \pm 0.15$ & $0.15 \pm 0.01$ \\
& nonirrigated & $46.80 \pm 0.98^{*}$ & $326.33 \pm 14.88^{*}$ & $2.79 \pm 0.12$ & $0.14 \pm 0.01$ \\
Vegetative flush (stage III) & irrigated & $40.45 \pm 1.87$ & $525.70 \pm 64.76$ & $1.08 \pm 0.16$ & $0.08 \pm 0.01$ \\
& nonirrigated & $39.42 \pm 0.43$ & $489.14 \pm 8.65$ & $1.17 \pm 0.02$ & $0.08 \pm 0.00$ \\
Flowering (stage IV) & irrigated & $43.04 \pm 3.78^{*}$ & $253.71 \pm 28.72$ & $3.42 \pm 0.10^{*}$ & $0.17 \pm 0.00^{*}$ \\
& nonirrigated & $33.34 \pm 0.05$ & $226.15 \pm 0.91$ & $2.91 \pm 0.02$ & $0.15 \pm 0.00$ \\
Fruit development (stage V) & irrigated & $17.09 \pm 0.11$ & $156.41 \pm 1.93$ & $2.00 \pm 0.01$ & $0.12 \pm 0.00$ \\
& nonirrigated & $35.65 \pm 4.21^{*}$ & $239.75 \pm 33.77^{*}$ & $2.95 \pm 0.00^{*}$ & $0.15 \pm 0.00^{*}$ \\
Maturity of fruit (stage VI) & irrigated & $16.49 \pm 0.68$ & $142.74 \pm 3.21$ & $2.20 \pm 0.20$ & $0.12 \pm 0.01$ \\
& nonirrigated & $21.23 \pm 2.57^{*}$ & $179.62 \pm 21.16^{*}$ & $2.25 \pm 0.02$ & $0.12 \pm 0.00$ \\
\hline
\end{tabular}

Table 2. Relationships between chlorophyll fluorescence parameters and fruit physicochemical properties in two phenological stages of the plant, vegetative flush (stage III) and maturity of fruit (stage VI). Pearson's correlation coefficient (r) are presented, where* $-p<0.05$, ${ }^{* *}-p<0.01,{ }^{* * *}-p<0.001, \mathrm{~ns}-$ not significant.

\begin{tabular}{|c|c|c|c|c|c|c|}
\hline \multirow[t]{2}{*}{ Parameters } & \multirow[t]{2}{*}{ Phenological stage } & \multicolumn{5}{|c|}{ Fruit physicochemical properties } \\
\hline & & Respiration & FM & PWL & TSS & TSS/TA \\
\hline \multirow[t]{2}{*}{$\mathrm{DI}_{0} / \mathrm{RC}$} & III & $-0.56^{* *}$ & ns & ns & ns & ns \\
\hline & VI & $0.50^{*}$ & ns & ns & ns & ns \\
\hline \multirow[t]{2}{*}{$\mathrm{ET}_{0} / \mathrm{RC}$} & III & ns & ns & ns & $\mathrm{ns}$ & $\mathrm{ns}$ \\
\hline & VI & ns & ns & ns & ns & ns \\
\hline \multirow{2}{*}{$\mathrm{RE}_{0} / \mathrm{RC}$} & III & $0.53^{*}$ & $-0.19^{\mathrm{ns}}$ & $0.19^{\text {ns }}$ & ns & ns \\
\hline & VI & $-0.38^{\mathrm{ns}}$ & $0.53^{*}$ & $-0.56^{*}$ & ns & ns \\
\hline \multirow{2}{*}{$\mathrm{PI}_{\mathrm{ABS}}$} & III & $0.73^{* * *}$ & ns & ns & ns & ns \\
\hline & VI & $-0.36^{\mathrm{ns}}$ & $\mathrm{ns}$ & $\mathrm{ns}$ & ns & ns \\
\hline \multirow[t]{2}{*}{$\mathrm{DF}_{\mathrm{ABS}}$} & III & $0.73^{* * *}$ & ns & ns & ns & $\mathrm{ns}$ \\
\hline & VI & $-0.39^{\mathrm{ns}}$ & ns & ns & ns & ns \\
\hline \multirow[t]{2}{*}{$\mathrm{PI}_{\mathrm{TOTAL}}$} & III & $0.77^{* * *}$ & ns & ns & ns & ns \\
\hline & VI & $-0.51^{*}$ & $\mathrm{~ns}$ & ns & $\mathrm{ns}$ & $\mathrm{ns}$ \\
\hline \multirow[t]{2}{*}{$\operatorname{Chl}(a+b)$} & III & $-0.33^{\mathrm{ns}}$ & ns & ns & $-0.06^{\mathrm{ns}}$ & $0.47^{*}$ \\
\hline & VI & $0.71^{* * *}$ & ns & $\mathrm{ns}$ & $0.56^{* *}$ & $0.02^{\mathrm{ns}}$ \\
\hline \multirow[t]{2}{*}{ Car } & III & $-0.33^{\mathrm{ns}}$ & $\mathrm{ns}$ & ns & $-0.06^{\mathrm{ns}}$ & $0.47^{*}$ \\
\hline & VI & $0.69^{* * *}$ & $\mathrm{~ns}$ & ns & $0.60^{* *}$ & $-0.05^{\mathrm{ns}}$ \\
\hline
\end{tabular}

for the fruits of irrigated plants, and $0.43 \mathrm{mmol}\left(\mathrm{CO}_{2}\right)$ $\mathrm{kg}^{-1}(\mathrm{FM}) \mathrm{h}^{-1}$ for the fruits of nonirrigated plants (Fig. 4).

\section{Discussion}

The performance index $\mathrm{PI}_{\mathrm{ABS}}$ and logarithm of $\mathrm{PI}_{\mathrm{ABS}}$, defined as the total driving force for photosynthesis $\left(\mathrm{DF}_{\mathrm{ABS}}\right)$, were used to assess differences in stress sensitivity of the plants (Jedmowski et al. 2013, Oukarroum et al. 2016). In vegetative stages (II and III) of the nonirrigated plants, the water supply from rainfall was sufficient to maintain the
PSII performance. The irrigated plants showed a decrease in the parameters $\mathrm{PI}_{\mathrm{ABS}}, \mathrm{PI}_{\mathrm{TOTAL}}$, and $\mathrm{DF}_{\mathrm{ABS}}$, which suggests that the irrigation during this period is not necessary. In parallel, in the vegetative stage, we also observed an increase in excitation energy dissipation at the PSII level $\left(\mathrm{DI}_{0} / \mathrm{RC}\right)$ in irrigated plants compared to nonirrigated ones. The energy dissipation parameter has been used as an indicator of drought stress in different plant species (Demetriou et al. 2007, Bacarin et al. 2011, CzyczyloMysza and Myśków 2017, Guo et al. 2018). Our research group has described previously a significant increase in 


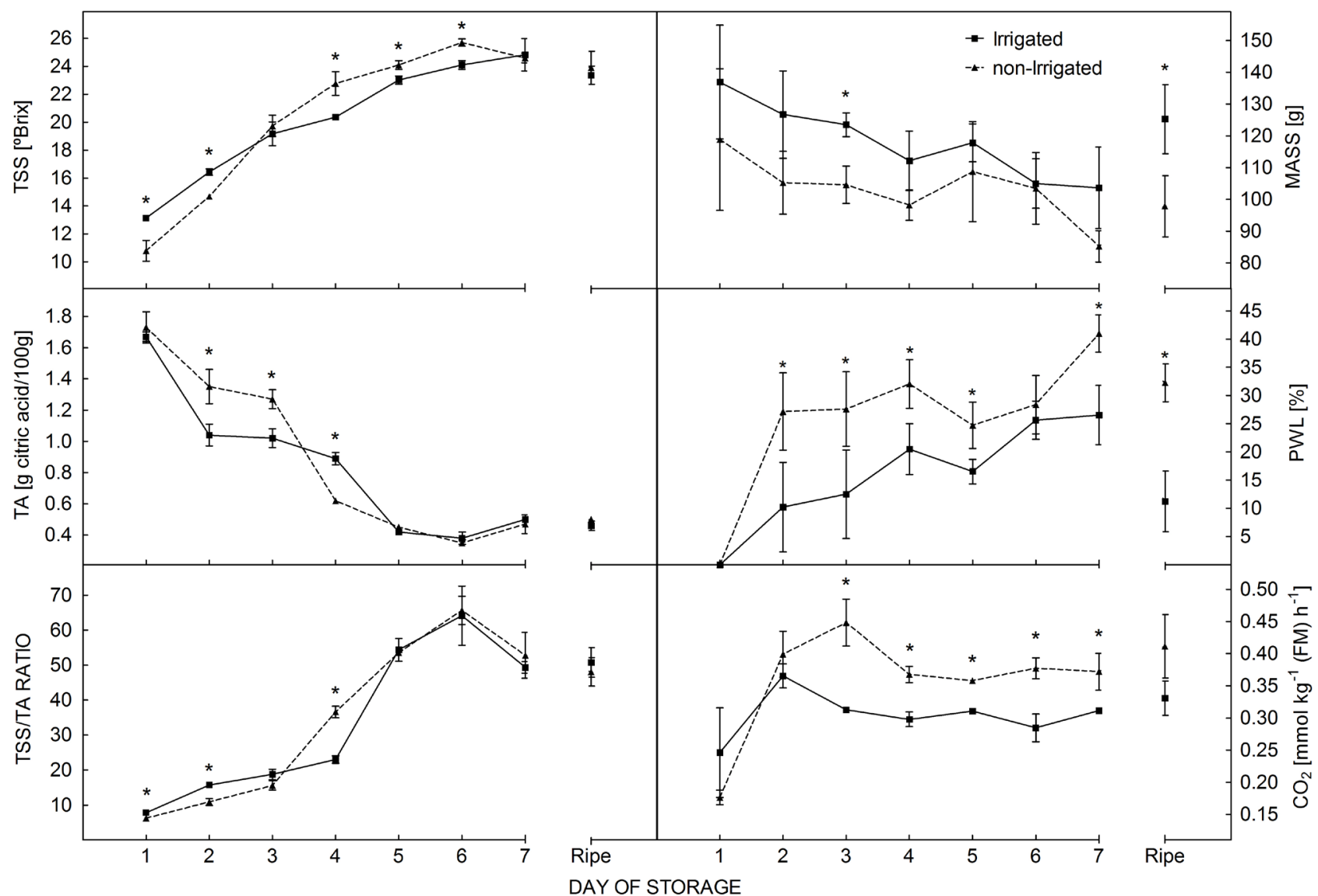

Fig. 4. Physicochemical properties, total soluble solids (TSS), titratable acidity (TA), TSS/TA ratio, mass, physiological mass loss (PWL), and respiration rate $\left(\mathrm{CO}_{2}\right)$ during the ripening process of 'Ubá' mango fruit from irrigated and nonirrigated plants. Data are means $\pm \mathrm{SD}, n=10$. Data were pairwise compared with Tukey's test and asterisk indicate the difference with $P \leq 0.05$.

$\mathrm{DI}_{0} / \mathrm{RC}$ after pruning in 'Ubá' mango trees exposed to light stress in the field (Faria-Silva et al. 2017). Hence, $\mathrm{DI}_{0} / \mathrm{RC}$ has been considered a potential indicator not only of a photoprotection mechanism but also of drought stress in the mango tree. Regarding the results for $\mathrm{ET}_{0} / \mathrm{RC}$ and $\mathrm{RE}_{0} / \mathrm{RC}$ parameters, in stage $\mathrm{I}$, there was no rainfall recorded before pruning (Fig. 3). In these conditions, additional water supply by irrigation ensured the maintenance of favorable photochemical conditions for the photosynthetic electron flow, evidenced by high $\mathrm{ET}_{0} / \mathrm{RC}$ and $\mathrm{RE}_{0} / \mathrm{RC}$ values compared to those in nonirrigated plants. Therefore, irrigation under these conditions has prevented the damage of the photosystems in the 'Ubá' mango leaves.

During the flowering stage (IV), no significant difference was observed between $\mathrm{Chl} a$ fluorescence parameters measured in irrigated and nonirrigated plants. These results show that there is no requirement for additional water supply during the flowering stage. In fact, water deficit during floral induction was shown to be important in the preflowering period, because it stimulates flowering ( $\mathrm{Lu}$ and Chacko 2000) and prevents flower abortion, which favors pollination and fruit quality (Laxman et al. 2016, Makhmale et al. 2016). Therefore, results obtained in this work agree with the idea that irrigation should be suppressed in the stage of vegetative flush (stage III), which means before the flowering stage.

In the fruit development (V) and fruit maturation (VI), our study showed that the irrigation guaranteed an increase in photochemical efficiency, and maintained the supply of photoassimilates in to the fruit, even in conditions of a reduced content of photosynthetic pigments. In addition, the increase in $\mathrm{ET}_{0} / \mathrm{RC}$ and $\mathrm{RE}_{0} / \mathrm{RC}$ parameters, and the decrease of the excitation energy dissipated in PSII $\left(\mathrm{DI}_{0} / \mathrm{RC}\right)$, led to higher values of $\mathrm{PI}_{\mathrm{ABS}}$ and $\mathrm{DF}_{\mathrm{ABS}}$. The fruiting period requires high amounts of photoassimilates from photosynthesis (Gifford et al. 1984, Poirier-Pocovi et al. 2018), and our study showed that proper water supply during the fruiting process is fundamental to enable a good function of the photosystems and the synthesis of photoassimilates.

On the other hand, water stress has considerable influence on the fruit set, its retention, and subsequent growth. Studies on other mango cultivars, as e.g., Haden, Tommy Atkins (Lu et al. 2012), Choke Anand, and Khieo Sawoei (Elsheery and Cao 2008), have demonstrated that water deficit decreases the photochemical efficiency of PSII in leaves, but, after water supply, the plants were able to recover, as it was observed for the 'Ubá' cultivar, evaluated in this work. In areas where prolonged dry seasons occur during flowering and fruiting period, irrigation is essential to ameliorate the adverse effects of drought stress 
(Davenport 2007). The proteins that constitute the reaction centers are the first to be disrupted by the water deficit, affecting the oxygen-evolution complex and reducing the efficiency with which the absorbed energy is transmitted between the units of PSII (Tsimilli-Michael and Strasser 2008, do Amaral et al. 2016). This reinforces the view that the lack of water affects the final production of photoassimilates, mainly during the phases of high demand (Hu et al. 1998, Saito et al. 2011).

In the present study, we observed the increase of total $\mathrm{Chl}$ under water stress. This effect, which has been little studied in perennial crops such as mango trees, is very common in corns, such as maize, wheat, rice, and sorghum, during the grain filling (Jiang et al. 2004, Zheng et al. 2009). According to Vadez et al. (2011) stay-green or slow leaf senescence during grain filling is a droughtresistance trait that increases yield in water-limited environments. Borrell et al. (2014) showed that the 'staygreen' characteristic in sorghum results from changes to plant growth in the vegetative phase that reduces canopy size at anthesis by modifying tillering, leaf number, and leaf size. The reduced canopy size at anthesis reduced the measured preflowering water use, leaving more soil water available for the postflowering period that maintained photosynthesis and delayed senescence (stay-green) and maturity. We also observed a significant increase in total $\mathrm{Chl}$ content during the fruit development, which is during the end of reproductive period, which suggests a similar mechanism of water stress tolerance. Moreover, it was observed an increase in Car content in leaves of nonirrigated plants. This fact supports the vital role of Car pigments in the protection of Chls since they widen the light-harvesting spectrum of $\mathrm{Chl}$ in the LHCII, protect the light-harvesting complex by nonphotochemical quenching of Chl triplet states, stabilize its structure, and regulate excitation energy transfer from LHCII to PSII via xanthophyll cycle (Tracewell et al. 2001, Ruban et al. 2007). In addition, the Car content increase in the leaves of nonirrigated plants might be related to the protective function of these pigments in the photosystems of the plants submitted to drought stress. The total Car content in leaves was high, from fruit development until after-pruning stage. The recovery of the photochemical performance of PSII was also observed by Lichtenthaler et al. (2007), who has studied the pigment composition and photosynthetic activity of sun and shade leaves of deciduous and coniferous trees. These authors observed a higher total Car content, as accessory pigments and photoprotectors, in the sun leaves.

The main effect of water deprivation on physical, chemical, and physiological characteristics of the fruits was the significant decrease in fruit fresh mass from nonirrigated trees. This negative effect of low water supply on the fruit size was described in other cultivars, such as cv. Osteen and cv. Cogshall (Durán Zuazo et al. 2011, Rosalie et al. 2015). In addition, as also observed in the present work, the drought stress during fruit development promotes TSS accumulation in mango (Ripoll et al. 2014).

Findings in the literature have indicated the third maturation stage, characterized by yellowish green color peel, soft yellow pulp, and high moisture content $\left(16.5^{\circ}\right.$ Brix $)$, is the best stage for harvesting and consuming 'Ubá' mango fruit (Oliveira et al. 2016). Our results demonstrate that the fruit can be harvested still unripe, around 11 and $13^{\circ}$ Brix, with a visual aspect of greenish skin color, which represents the physiological maturity of the fruit. Harvesting fruit at this maturity stage revealed a flavor quality equal to the fruits harvested ready for consumption after storage during 5, 6, and $7 \mathrm{~d}$ at $25^{\circ} \mathrm{C}$. Hence, the fruits harvested at the physiological maturity were considered good for consumption after the fifth day of ripening, which represents an average of $23.4^{\circ}$ Brix, $0.5 \mathrm{~g}$ (citric acid) $100 \mathrm{~g}^{-1}$ (pulp), and a TSS/TA ratio of 51.5. Increasing the time of fruit commercialization in the productive chain is relevant to the farmer and to the juice industry.

Mango fruits harvested at the physiological maturity stage showed an increase in the respiratory activity $2 \mathrm{~d}$ after harvest, regardless the water regime. We believe that this increase is related to the climacteric peak, although ethylene production was not evaluated in this work. Da Silva et al. (2012) reported that biochemical transformations triggered in climacteric fruits start in the preclimacteric. An increase in TSS and a reduction in TA are common as the fruit ripens (Hoa et al. 2002, Oliveira et al. 2016). Yashoda et al. (2006) demonstrated the starch to sugar conversion during ripening of the mango fruit, cv. Alphonso. Further, acid reduction is common during fruit ripening (Eyarkai Nambi et al. 2015). It is interesting to note that ripe fruits harvested from irrigated plants had the same quality as fruits harvested from plants rainfed only.The ripe harvested fruits of irrigated plants, considered ready for consumption, presented higher fresh mass. According to Spreer et al. (2009), mango trees of cv. Choc Anan, which have been irrigated successively during three years, were more productive, and the fruits were heavier than the fruits of plants grown just in rainfed conditions. Hence, it is expected a high energetic demand for photoassimilates during the fruiting of nonirrigated plants. However, it is worth considering that the difference in mass loss observed between irrigated and nonirrigated plants might be also related to the loss of water to the environment, according to the conditions of storage (Sousa et al. 2002).

Although it is possible to observe some physicochemical differences between fruits of irrigated and nonirrigated plants during the postharvest maturation process, it is important to note that at the end of maturation, the fruits from plants grown under both water regimes had the same postharvest qualities. In addition to this, the quality was equivalent to the fruit harvested fully ripe from the tree. This means that at the end of ripening, the fruits harvested at physiological maturity presented qualities that were statistically similar to the fruits harvested ripe.

It is therefore suggested that the water availability for 'Ubá' plants is extremely important during the fruiting stage in a sense that water constraint also interferes with parameters of fruit quality. Rossouw et al. (2017) also suggested that the carbohydrate reserves are distributed to different plant organs, and the concentration and partitioning between different organs vary throughout growing stages. The results presented in this work provide 
information supporting the hypothesis that the water availability during specific developmental stages is crucial to maintain the benefits of irrigation to the photochemical metabolism of 'Ubá' mango tree, as it is enhancing the plant ability to cope with fruiting demands under limited water availability.

Our study elucidated the role of additional water supply on photosynthesis during specific stages of the mango tree development, as shown for peach (Zhang et al. 2018), when the efficient use of light by photosynthetic apparatus has significant effects on fruit quality. In the present work, we observed damages in the photosynthetic performance in the plants loaded with matured fruits, under limiting water supply conditions, which were demonstrated by the decrease in the photochemical performance index of PSI

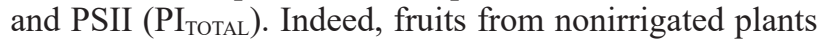
considering fruits harvested at the physiological maturity, had lower fresh mass in relation to fruits from irrigated plants.

The relationship between ripening and senescence of Chl-containing tropical fruits was studied using Chl fluorescence in the skin of the fruits (Smillie et al. 1987, Bron et al. 2004, Léchaudel et al. 2013). Indeed, Léchaudel et al. (2010) observed changes in Chl fluorescence parameters in fruits attached to trees as an indicator of fruit maturity, suggesting the relationship between mango maturity and the decrease of Chl fluorescence parameters. Recently, Faria-Silva et al. (2017) demonstrated the effects of temperature stress in Chl fluorescence of mango trees, with a decrease in $\mathrm{PI}_{\text {TOTAL }}$ of leaves and an increase in TSS of fruits. In the present work, with the studies of the vegetative and reproductive stages of mango tree, we correlated the changes in $\mathrm{Chl}$ fluorescence parameters in the leaves with fruit quality parameters. The correlation analysis indicated that higher significant levels were found in stages III and VI, which represented the vegetative and reproductive development, respectively (Table 2). The results showed that in the vegetative phase, the respiratory rate of the fruit had a positive correlation with the $\mathrm{PI}_{\mathrm{ABS}}(r=0.73), \mathrm{RE}_{0} / \mathrm{RC}(r=0.53)$, and $\mathrm{PI}_{\mathrm{TOTAL}}$ $(r=0.77)$ of leaves of irrigated and nonirrigated plants. Otherwise, in the reproductive phase, the respiratory rate of the fruit was negatively correlated with $\mathrm{PI}_{\text {TOTAL }}$ $(r=-0.51)$ in the leaves. It seems that in the reproductive phase, when the plant is dealing with the fruiting process, there is a demand for photoassimilates (accumulated during vegetative phase) reflected by the decrease of total performance index in the leaves.

We concluded that additional water supply by irrigation is relevant to photochemical performance just when fruiting demand for photoassimilates is elevated, which is during fruit development and maturity. In addition, good agronomic practices have an impact on avoiding the waste of water, especially in the actual changing climatic scenario.

\section{References}

Amaral M.N., Arge L.W.P., Benitez L.C. et al.: Differential expression of photosynthesis-related genes and quantification of gas exchange in rice plants under abiotic stress. - Acta Physiol. Plant. 38: 153, 2016.

Bacarin M.A., Deuner S., da Silva F.S.P. et al.: Chlorophyll $a$ fluorescence as indicative of the salt stress on Brassica napus L. - Braz. J. Plant Physiol. 23: 261-266, 2011.

Borrell A.K., Mullet J.E., George-Jaeggli B. et al.: Drought adaptation of stay-green sorghum is associated with canopy development, leaf anatomy, root growth, and water uptake. J. Exp. Bot. 65: 6251-6263, 2014.

Bron I.U., Ribeiro R.V., Azzolini M. et al.: Chlorophyll fluorescence as a tool to evaluate the ripening of "Golden" papaya fruit. - Postharvest Biol. Tec. 33: 163-173, 2004.

Carr M.K.V.: The water relations and irrigation requirements of mango (Mangifera indica L.): A review. - Exp. Agr. 50: 1-23, 2014.

Czyczyło-Mysza I., Myśków B.: Analysis of the impact of drought on selected morphological, biochemical and physiological traits of rye inbred lines. - Acta Physiol. Plant. 39: 87, 2017.

Davenport T.L.: Reproductive physiology of mango. - Braz. J. Plant Physiol. 19: 363-376, 2007.

Demetriou G., Neonaki C., Navakoudis E., Kotzabasis K.: Salt stress impact on the molecular structure and function of the photosynthetic apparatus - the protective role of polyamines. BBA-Bioenergetics 1767: 272-280, 2007.

do Amaral M.N., Arge L.W.P., Benitez L.C. et al.: Differential expression of photosynthesis-related genes and quantification of gas exchange in rice plants under abiotic stress. - Acta Physiol. Plant. 38: 153, 2016.

Durán Zuazo V.H., Pleguezuelo C.R.R., Tarifa D.F.: Impact of sustained-deficit irrigation on tree growth, mineral nutrition, fruit yield and quality of mango in Spain. - Fruits 66: 257-268, 2011.

Einali A., Shariati M.: Effects of propyl gallate on photosystem II efficiency in Dunaliella bardawil under high illumination as investigated by chlorophyll fluorescence measurements. Theor. Exp. Plant Phys. 27: 61-73, 2015.

Elsheery N.I., Cao K.-F.: Gas exchange, chlorophyll fluorescence, and osmotic adjustment in two mango cultivars under drought stress. - Acta Physiol. Plant. 30: 769-777, 2008.

Eyarkai Nambi V., Thangavel K., Manohar Jesudas D.: Scientific classification of ripening period and development of colour grade chart for Indian mangoes (Mangifera indica L.) using multivariate cluster analysis. - Sci. Hortic.-Amsterdam 193: 90-98, 2015.

Faria-Silva L., Gallon C.Z., Purgatto E. et al.: Photochemical metabolism and fruit quality of 'Ubá' mango tree exposed to combined light and heat stress in the field. - Acta Physiol. Plant. 39: 238, 2017.

Gifford R.M., Thorne J.H., Hitz W.D., Giaquinta R.T.: Crop productivity and photoassimilate partitioning. - Science $\mathbf{2 2 5}$ : 801-808, 1984.

González A., Lu P., Müller W.: Effect of pre-flowering irrigation on leaf photosynthesis, whole-tree water use and fruit yield of mango trees receiving two flowering treatments. - Sci. Hortic.-Amsterdam 102: 189-211, 2004.

Guo Y.Y., Tian S.S., Liu S.S. et al.: Energy dissipation and antioxidant enzyme system protect photosystem II of sweet sorghum under drought stress. - Photosynthetica 56: 861-872, 2018.

Hernández Delgado P.M., Aranguren M., Reig C. et al.: Phenological growth stages of mango (Mangifera indica L.) according to the BBCH scale. - Sci. Hortic.-Amsterdam 130: 536-540, 2011.

Hoa T.T., Ducamp M.N., Lebrun M., Baldwin E.A.: Effect of different coating treatments on the quality of mango fruit. J. Food Quality 25: 471-486, 2002.

Hu Q., Miyashita H., Iwasaki I. et al.: A photosystem I reaction 
center driven by chlorophyll $d$ in oxygenic photosynthesis. P. Natl. Acad. Sci. USA 95: 13319-13323, 1998.

Jedmowski C., Ashoub A., Brüggemann W.: Reactions of Egyptian landraces of Hordeum vulgare and Sorghum bicolor to drought stress, evaluated by the OJIP fluorescence transient analysis. - Acta Physiol. Plant. 35: 345-354, 2013.

Jiang G.H., He Y.Q., Xu C.G. et al.: The genetic basis of staygreen in rice analyzed in a population of doubled haploid lines derived from an indica by japonica cross. - Theor. Appl. Genet. 108: 688-698, 2004.

Kalaji H.M., Jajoo A., Oukarroum A. et al: Chlorophyll $a$ fluorescence as a tool to monitor physiological status of plants under abiotic stress conditions. - Acta Physiol. Plant. 38: 102, 2016.

Kalaji H.M., Schansker G., Brestič M. et al: Frequently asked questions about chlorophyll fluorescence, the sequel. Photosynth. Res. 132: 13-66, 2017.

Laxman R.H., Annapoornamma C.J., Biradar G.: Mango. In: Rao N.K.S., Shivashankara K.S., Laxman R.H. (ed.): Abiotic Stress Physiology of Horticultural Crops. Pp. 169-181. Springer India, New Delhi 2016.

Léchaudel M., Lopez-Lauri F., Vidal V. et al.: Response of the physiological parameters of mango fruit (transpiration, water relations and antioxidant system) to its light and temperature environment. - J. Plant. Physiol. 170: 567-576, 2013.

Léchaudel M., Urban L., Joas J.: Chlorophyll fluorescence, a nondestructive method to assess maturity of mango fruits (cv. 'Cogshall') without growth conditions bias. - J. Agr. Food Chem. 58: 7532-7538, 2010.

Lichtenthaler H.K., Ač A., Marek M. V. et al.: Differences in pigment composition, photosynthetic rates and chlorophyll fluorescence images of sun and shade leaves of four tree species. - Plant Physiol. Bioch. 45: 577-588, 2007.

Lichtenthaler H.K., Buschmann C.: Chlorophylls and carotenoids: Measurement and characterization by UV-VIS. - Curr. Protoc. Food Anal. Chem. 1: F4.3.1-F4.3.8., 2001.

$\mathrm{Lu}$ P., Chacko E.K.: Effect of water stress on mango flowering in low latitude tropics of Northern Australia. - Acta Hortic. 509: 283-289, 2000.

Lu P., Chacko E.K., Bithell S.L. et al.: Photosynthesis and stomatal conductance of five mango cultivars in the seasonally wet-dry tropics of northern Australia. - Sci. Hortic.-Amsterdam 138: 108-119, 2012.

Lucena E.M.P., Assi J.S., Alves R.E. et al.: [Physical and chemical changes during Tommy Atkins mangoes development in São Francisco valley, Petrolina, PE, Brazil.] - Rev. Bras. Frutic. 29: 96-101, 2007. [In Portuguese]

Makhmale S., Bhutada P., Yadav L., Yadav B.K.: Impact of climate change on phenology of Mango - The case study. Ecol. Environ. Conserv. 22: 119-124, 2016.

Oliveira B.G., Costa H.B., Ventura J.A. et al.: Chemical profile of mango (Mangifera indica L.) using electrospray ionization mass spectrometry (ESI-MS). - Food Chem. 204: 37-45, 2016.

Oliveira R.A., Tagliaferre C., Sediyama G.C. et al.: [Performance of the "Irrigâmetro" in the estimation of reference evapotranspiration.] - Rev. Bras. Eng. Agr. Amb. 12: 166173, 2008. [In Portuguese]

Oukarroum A., El Madidi S., Strasser R.J.: Differential heat sensitivity index in barley cultivars (Hordeum vulgare L.) monitored by chlorophyll $a$ fluorescence OKJIP. - Plant Physiol. Bioch. 105: 102-108, 2016.

Poirier-Pocovi M., Lothier J., Buck-Sorlin G.: Modelling temporal variation of parameters used in two photosynthesis models: Influence of fruit load and girdling on leaf photosynthesis in fruit-bearing branches of apple. - Ann. Bot. 121: 821-832, 2018.
Pongsomboon W., Subhadrabandhu S., Stephenson R.A.: Some aspects of the ecophysiology of flowering intensity of mango (Mangifera indica L.) cv. Nam Dok Mai in a semi-tropical monsoon Asian climate. - Sci. Hortic.-Amsterdam 70: 45-56, 1997.

Ripoll J., Urban L., Staudt M. et al.: Water shortage and quality of fleshy fruits - making the most of the unavoidable. - J. Exp. Bot. 65: 4097-4117, 2014.

Rosalie R., Joas J., Deytieux-Belleau C. et al: Antioxidant and enzymatic responses to oxidative stress induced by preharvest water supply reduction and ripening on mango (Mangifera indica L. cv. 'Cogshall') in relation to carotenoid content. - J. Plant Physiol. 184: 68-78, 2015.

Rossouw G.C., Smith J.P., Barril C. et al.: Carbohydrate distribution during berry ripening of potted grapevines: Impact of water availability and leaf-to-fruit ratio. - Sci. Hortic.-Amsterdam 216: 215-225, 2017.

Ruban A.V., Berera R., Ilioaia C. et al.: Identification of a mechanism of photoprotective energy dissipation in higher plants. - Nature 450: 575-578, 2007.

Saito K., Ishida T., Sugiura M. et al.: Distribution of the cationic state over the chlorophyll pair of the photosystem II reaction center. - J. Am. Chem. Soc. 133: 14379-14388, 2011.

Silva D.F.P., Salomão L.C.C., Siqueira D.L. et al.: Ripening of 'Ubá' mango using ethylene and calcium carbide - Ciênc. Rural 42: 213-220, 2012.

Skrobot V.L., Castro E.V.R., Pereira R.C.C. et al.: Use of principal component analysis (PCA) and linear discriminant analysis (LDA) in gas chromatographic (GC) data in the investigation of gasoline adulteration. - Energ. Fuel. 21: 3394-3400, 2007.

Smillie R.M., Hetherington S.E., Nott R. et al.: Applications of chlorophyll fluorescence to the postharvest physiology and storage of mango and banana fruit and the chilling tolerance of mango cultivars. - ASEAN Food J. 3: 55-59, 1987.

Sousa J.P., Praça E.F., Alves R.E. et al.: [Influence of refrigerated storage associated with plastic film-modified atmosphere in quality of 'Tommy Atkins' mangoes.] - Rev. Bras. Frutic. 24: 665-668, 2002. [In Portuguese]

Spreer W., Ongprasert S., Hegele M. et al.: Yield and fruit development in mango (Mangifera indica L. cv. Chok Anan) under different irrigation regimes. - Agr. Water Manage. 96: 574-584, 2009.

Stirbet A., Govindjee: On the relation between the Kautsky effect (chlorophyll $a$ fluorescence induction) and Photosystem II: Basics and applications of the OJIP fluorescence transient. J. Photoch. Photobio. B 104: 236-257, 2011.

Stirbet A., Lazár D., Kromdijk J., Govindjee: Chlorophyll a fluorescence induction: Can just a one-second measurement be used to quantify abiotic stress responses? - Photosynthetica 56: 86-104, 2018.

Stirbet A., Riznichenko G.Y., Rubin A.B., Govindjee: Modeling chlorophyll $a$ fluorescence transient: relation to photosynthesis. - Biochemistry 79: 291-323, 2014.

Strasser B.J., Strasser R.J.: Measuring fast fluorescence transients to address environmental questions: The JIP-test. In: Mathis P. (ed.): Photosynthesis: From Light to Biosphere. Pp. 977-980. Kluwer Academic Publishers, Dordrecht 1995.

Strasser R.J., Tsimilli-Michael M., Qiang S., Goltsev V.: Simultaneous in vivo recording of prompt and delayed fluorescence and $820-\mathrm{nm}$ reflection changes during drying and after rehydration of the resurrection plant Haberlea rhodopensis. BBA-Bioenergetics 1797: 1313-1326, 2010.

Strasser R.J., Tsimilli-Michael M., Srivastava A.: Analysis of the chlorophyll $a$ fluorescence transient. - In: Papageorgiou G.C., Govindjee (ed.): Chlorophyll $a$ Fluorescence: A Signature of Photosynthesis. Advances in Photosynthesis and Respiration. 
Pp. 321-362. Springer, Dordrecht 2004.

Tracewell C.A., Trettos J.S., Bautista J.A. et al:: Carotenoid photooxidation in photosystem II. - Arch. Biochem. Biophys. 385: 61-69, 2001.

Tsimilli-Michael M., Strasser R.J.: In vivo assessment of stress impact on plants' vitality: applications in detecting and evaluating the beneficial role of mycorrhization on host plants.In: Varma A. (ed.): Mycorrhiza. State of the Art, Genetics and Molecular Biology, Eco-Function, Biotechnology, EcoPhysiology, Structure and Systematics. $3^{\text {rd }}$ edition. Pp. 679-703. Springer, Berlin-Heidelberg 2008.

Vadez V., Deshpande S.P., Kholova J. et al.: Stay-green quantitative trait loci's effects on water extraction, transpiration efficiency and seed yield depend on recipient parent background. - Funct. Plant Biol. 38: 553-566, 2011.

Van Wittenberghe S., Alonso L., Verrelst J. et al.: Bidirectional sun-induced chlorophyll fluorescence emission is influenced by leaf structure and light scattering properties - A bottom-up approach. - Remote Sens. Environ. 158: 169-179, 2015.

Wang W., Vincur B., Altman A.: Plant responses to drought, salinity and extreme temperatures: towards genetic engineering for stress tolerance. - Planta 218: 1-14, 2003.

Yashoda H.M., Prabha T.N., Tharanathan R.N.: Mango ripening: Changes in cell wall constituents in relation to textural softening. - J. Sci. Food Agr. 86: 713-721, 2006.

Zhang B.B., Xu J.L., Zhou M. et al.: Effect of light quality on leaf photosynthetic characteristics and fruit quality of peach (Prunus persica L. Batch). - Photosynthetica 56: 1113-1122, 2018.

Zheng H.J., Wu A.Z., Zheng C.C. et al.: QTL mapping of maize (Zea mays) stay-green traits and their relationship to yield. Plant Breeding 128: 54-62, 2009.

Appendix. Abbreviations, formulae, and definitions of terms of the JIP-test used for the analysis of the Chl $a$ fluorescence transient (OJIP) emitted by dark-adapted photosynthetic samples, according to Strasser et al. (2010) and Stirbet and Govindjee (2011).

\begin{tabular}{|c|c|c|}
\hline Abbreviations & Formulae & Definitions \\
\hline $\mathrm{F}_{0}$ & $\mathrm{~F}=20 \mu \mathrm{s}$ & $\begin{array}{l}\text { minimal fluorescence intensity, when all photosystem II (PSII) reaction centers (RCs) } \\
\text { are open }\end{array}$ \\
\hline $\mathrm{F}_{\mathrm{J}}$ & $\mathrm{F}=2 \mathrm{~ms}$ & fluorescence during the J-step \\
\hline $\mathrm{F}_{\mathrm{M}}$ & $\mathrm{F} \sim 400 \mathrm{~ms}$ & maximal fluorescence intensity, when all PSII RCs are closed \\
\hline $\mathrm{F}_{\mathrm{V}}$ & $\mathrm{F}_{\mathrm{M}}-\mathrm{F}_{0}$ & maximal variable fluorescence \\
\hline $\mathrm{F}_{\mathrm{V}} / \mathrm{F}_{\mathrm{M}}$ & $1-\left(\mathrm{F}_{0} / \mathrm{F}_{\mathrm{M}}\right)$ & maximal quantum efficiency of PSII \\
\hline $\mathrm{M}_{0}$ & $4\left(\mathrm{~F}_{300 \mu \mathrm{s}}-\mathrm{F}_{0}\right) /\left(\mathrm{F}_{\mathrm{M}}-\mathrm{F}_{0}\right)$ & approximate value of the initial slope of relative variable chlorophyll fluorescence curve \\
\hline $\mathrm{V}_{\mathrm{J}}$ & $\left(\mathrm{F}_{\mathrm{J}}-\mathrm{F}_{0}\right) /\left(\mathrm{F}_{\mathrm{M}}-\mathrm{F}_{0}\right)$ & relative variable fluorescence at the J-step \\
\hline $\mathrm{dV} / \mathrm{dt}_{0}=\mathrm{M}_{0}$ & $\mathrm{M}_{0}$ & slope at the origin of the fluorescence rise \\
\hline $\mathrm{dVG} / \mathrm{dt}_{0}$ & - & excitation energy transfer between the RCs \\
\hline $\mathrm{ABS} / \mathrm{RC}$ & $\mathrm{M}_{0}\left(1 / \mathrm{V}_{\mathrm{J}}\right)\left(1 / \varphi \mathrm{P}_{0}\right)$ & absorption energy flux per active $\mathrm{RC}$ \\
\hline $\mathrm{TR}_{0} / \mathrm{RC}$ & $\mathrm{M}_{0}\left(1 / \mathrm{V}_{\mathrm{J}}\right)$ & flux of excitation energy trapped per active RC \\
\hline $\mathrm{DI}_{0} / \mathrm{RC}$ & $\mathrm{ABS} / \mathrm{RC}-\mathrm{TR}_{0} / \mathrm{RC}$ & total energy dissipated per active $\mathrm{RC}$ as heat (at $t=0$ ) \\
\hline $\mathrm{ET}_{0} / \mathrm{RC}$ & $\left(\mathrm{M}_{0} / \mathrm{V}_{\mathrm{J}}\right)\left(1-\mathrm{V}_{\mathrm{J}}\right)$ & transported electron flux per $\mathrm{RC}$, further than reduced quinone acceptor $\left(\mathrm{Q}_{\mathrm{A}}^{-}\right)$ \\
\hline $\mathrm{RE}_{0} / \mathrm{RC}$ & $\mathrm{M}_{0}\left(1 / \mathrm{V}_{\mathrm{J}}\right) \psi \mathrm{E}_{0} \delta \mathrm{R}_{0}$ & $\begin{array}{l}\text { electron flux transferred per RC and reducing terminal acceptors on the acceptor side of } \\
\text { photosystem I (PSI) at } t=0\end{array}$ \\
\hline$\psi \mathrm{E}_{0}$ & $1-\mathrm{V}_{\mathrm{J}}$ & efficiency with which a PSII trapped electron is transferred from $Q_{A}$ to $Q_{B}$ \\
\hline$\delta \mathrm{R}_{0}$ & $\left(1-\mathrm{V}_{\mathrm{I}}\right) /\left(1-\mathrm{V}_{\mathrm{J}}\right)$ & efficiency with which an electron from $\mathrm{Q}_{\mathrm{B}}$ is transferred until PSI acceptors \\
\hline$\varphi \mathrm{P}_{0}$ & $1-\mathrm{F}_{0} / \mathrm{F}_{\mathrm{M}}$ & maximum quantum yield of primary PSII photochemistry \\
\hline$\varphi \mathrm{E}_{0}$ & $1-\mathrm{F}_{\mathrm{J}} / \mathrm{F}_{\mathrm{M}}$ & quantum yield for electron transport \\
\hline$\varphi \mathrm{R}_{0}$ & $1-\mathrm{F}_{\mathrm{I}} / \mathrm{F}_{\mathrm{M}}$ & quantum yield of the electron transport flux until the PSI electron acceptors \\
\hline $\mathrm{PI}_{\mathrm{ABS}}$ & $\begin{array}{l}(\mathrm{RC} / \mathrm{ABS})\left[\varphi \mathrm{P}_{0} /\left(1-\varphi \mathrm{P}_{0}\right)\right] \\
{\left[\psi \mathrm{E}_{0} /\left(1-\psi \mathrm{E}_{0}\right)\right]}\end{array}$ & $\begin{array}{l}\text { performance index for energy conservation from photons absorbed by PSII to the } \\
\text { reduction of intersystem electron acceptors }\end{array}$ \\
\hline $\mathrm{DF}_{\mathrm{ABS}}$ & $\log \left(\mathrm{PI}_{\mathrm{ABS}}\right)$ & driving forces in PSII with respect to absorption \\
\hline $\mathrm{PI}_{\mathrm{TOTAL}}$ & $\mathrm{PI}_{\mathrm{ABS}}\left[\delta \mathrm{R}_{0} /\left(1-\delta \mathrm{R}_{0}\right)\right]$ & $\begin{array}{l}\text { performance index for energy conservation from photons absorbed by PSII to the } \\
\text { reduction of PSI end acceptors }\end{array}$ \\
\hline $\mathrm{DF}_{\text {TOTAL }}$ & $\log \left(\mathrm{PI}_{\mathrm{TOTAL}}\right)$ & estimated sum of individual components involved in the PSII-driven processes \\
\hline $\mathrm{RC} / \mathrm{ABS}$ & $\varphi \mathrm{P}_{0}\left(\mathrm{~V}_{\mathrm{J}} / \mathrm{M}_{0}\right)$ & number of $\mathrm{Q}_{\mathrm{A}}$ reducing $\mathrm{RCs}$ per PSII antenna chlorophyll \\
\hline $\mathrm{RC} / \mathrm{CS}_{0}$ & $(\mathrm{RC} / \mathrm{ABS})\left(\mathrm{ABS} / \mathrm{CS}_{0}\right)$ & density of RCs per excited cross section (CS) \\
\hline
\end{tabular}

(c) The authors. This is an open access article distributed under the terms of the Creative Commons BY-NC-ND Licence. 